University of South Florida

DIGITAL COMMONS

@ UNIVERSITY OF SOUTH FLORIDA
Digital Commons @ University of

South Florida

$4-1-2004$

\title{
Model Regulations and Plan Amendments for Multimodal Transportation Districts
}

CUTR

Follow this and additional works at: https://digitalcommons.usf.edu/cutr_nctr

\section{Scholar Commons Citation}

CUTR, "Model Regulations and Plan Amendments for Multimodal Transportation Districts" (2004).

Research Reports. 230.

https://digitalcommons.usf.edu/cutr_nctr/230

This Technical Report is brought to you for free and open access by the National Center for Transit Research (NCTR) Archive (2000-2020) at Digital Commons @ University of South Florida. It has been accepted for inclusion in Research Reports by an authorized administrator of Digital Commons @ University of South Florida. For more information, please contact digitalcommons@usf.edu. 


\title{
Model Regulations and Plan Amendments for Multimodal Transportation Districts
}



Prepared by:

Kristine M. Williams, AICP Karen E. Seggerman, AICP

\section{Project Manager:}

Martin Guttenplan, AICP

Systems Planning Office

Florida Department of Transportation

\author{
National Center for Transit Research \\ Center for Urban Transportation Research \\ University of South Florida \\ 4202 E. Fowler Avenue, CUT100 \\ Tampa, FL 33620-5375
}

(813) 974-3120 




State of Florida Department of Transportation

605 Suwannee Street, MS-49

Tallahassee, FL 32399-0450

(850) 410-5700

Project Manager:

Martin Guttenplan, AICP

Transportation Planner



\author{
National Center for Transit Research \\ Center for Urban Transportation Research \\ University of South Florida \\ 4202 E. Fowler Avenue, CUT100 \\ Tampa, FL 33620-5375 \\ (813) 974-3120 \\ http://www.nctr.usf.edu
}

The opinions, findings, and conclusions expressed in this publication are those of the authors and not necessarily those of the U.S. Department of Transportation or the State of Florida Department of Transportation. 


\section{Report No. FDOT: BC-137-47 \\ NCTR: 2117052700 No. \\ 4. Title and Subtitle \\ Model Regulations and Plan Amendments for Multimodal Transportation \\ Districts}

\section{Government Accession 3. Recipient's Catalog No.}

5. Report Date February 2004

6. Performing Organization Code

7. Author(s)

Kristine M. Williams, AICP, Karen E. Seggerman, AICP, Irene Nikitopoulos

8. Performing Organization Report No.

9. Performing Organization Name and Address

10. Work Unit No.

National Center for Transportation Research

Center for Urban Transportation Research

University of South Florida

4202 E. Fowler Avenue, CUT 100, Tampa FL 33620-5375

\section{Sponsoring Agency Name and Address}

13. Type of Report and Period

Office of Research and Special Programs

U.S. Department of Transportation, Washington, D.C. 20690

Florida Department of Transportation

605 Suwannee Street, MS 26, Tallahassee, FL 32399

11. Contract or Grant No.

DTRS 98-9-0032

Covered

14. Sponsoring Agency Code

15. Supplementary Notes

Supported by a grant from the Florida Department of Transportation and the U.S. Department of Transportation

16. Abstract

In 1999, the Florida legislature enabled local governments to establish Multimodal Transportation Districts [MMTD) in their comprehensive plan as a means of promoting a high quality multimodal environment within selected urban areas. The Florida Department of Transportation and its partners have engaged in several projects to support a more multimodal approach to transportation and development planning. These efforts have included development of multimodal level of service standards, as well as procedures for determining multimodal level of service and concurrency. This project builds on that work by providing model comprehensive plan amendments and land development regulations to assist local governments in implementing multimodal transportation districts, where priority is placed on walking, bicycling and transit use through a coordinated package of land use and transportation strategies.

17. Key Words

Multimodal, transit-friendly development, livable communities

19. Security Classif. (of this report) Unclassified

Form DOT F 1700.7 (8-69)
Distribution Statement

Available to public through the National Technical Information Service (NTIS), 5285 Port Royal, Springfield, VA 22181 ph (703) 487-4650

20. Security Classif. (of this page)

21. No. of pages: 44

22. Price 


\section{ACKNOWLEDGMENTS}

This report is prepared by the National Center for Transit Research at the Center for Urban Transportation Research, College of Engineering, University of South Florida, through the sponsorship of the Florida Department of Transportation and the U.S. Department of Transportation.

FDOT Project Manager:

Martin Guttenplan, AICP, Systems Planning Office, Florida Department of Transportation

\section{CUTR Project Team}

\section{Principal Authors:}

Kristine M. Williams, AICP, Program Director, Planning \& Corridor Management

Karen E. Seggerman, AICP, Senior Research Associate, Planning \& Corridor Management

Research Assistant:

Irene Nikitopoulos, Research Assistant, Planning \& Corridor Management

Contributors and Reviewers:

Beverly Ward, Program Director, Ethnography and Transport Systems

Sara Hendricks, AICP, Senior Research Associate, Transportation Demand Management 


\section{TABLE OF CONTENTS}



What is a Multimodal Transportation District.................................................

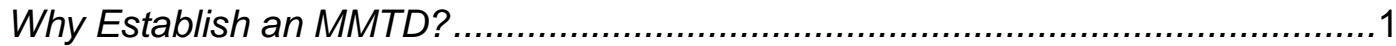







Part II: $\quad$ Model Comprehensive Plan Amendments..............................................

Part III: $\quad$ Model Land Development Regulations ................................................17

Section 1: General Requirements ....................................................... 17





Section 4: Traffic Calming ..................................................................2



Section 6: Transit Facilities .....................................................................26

Section 7: Sidewalks and Pedestrian Facilities..........................................27

Section 8: Bicycle Facilities................................................................29



Section 10: Application for Development in MMTDs........................................33

Section 11: Incentives ........................................................................... 34

Part IV: $\quad$ References and Bibliography..........................................................36 



\section{PART I: INTRODUCTION}

In 1999, the Florida legislature amended Chapter 163, Florida Statutes, commonly known as the Growth Management Act, authorizing local governments to establish multimodal transportation districts. The purpose of the legislation was to provide a planning tool that Florida communities could use to systematically reinforce community design elements that support walking, bicycling and transit use. It also enabled Florida communities to advance transportation concurrency-a policy requirement that transportation facilities be available concurrent with the impacts of developmentthrough development of a high quality multimodal environment, rather than the typical approach involving road widening for automobile capacity.

Multimodal transportation districts (MMTDs) are to be carried out through local comprehensive plans, land development regulations, and capital improvements programs. This report provides model comprehensive plan amendments and model regulations for multimodal transportation districts to assist local governments in Florida. It is based on a national review of multimodal policies, ordinances, and practices at the local level and a synthesis of best practices. The report begins with an overview of the purpose and statutory requirements for multimodal transportation districts in Florida, and continues with model comprehensive plan amendments and land development regulations to assist local governments in implementing MMTDs.

\section{What is a Multimodal Transportation District?}

A multimodal transportation district is an area where primary priority is placed on "assuring a safe, comfortable, and attractive pedestrian environment, with convenient interconnection to transit" (1). Communities must incorporate community design features that reduce vehicular usage while supporting an integrated multimodal transportation system. Common elements include the presence of mixed-use activity centers, connectivity of streets and land uses, transit-friendly design features, and accessibility to alternative modes of transportation.

The Florida Department of Transportation has developed a Multimodal Transportation Districts and Areawide Quality of Service Handbook (FDOT 2004) to provide guidance on the designation and planning of MMTDs as provided in Florida's growth management legislation. The handbook provides for MMTD designation in a downtown or urban core area, regional activity center, or traditional town or village in accordance with certain criteria. In these areas, planning efforts would focus on enhancing multimodal elements, guiding redevelopment, and encouraging appropriate infill. An MMTD could also be applied to a new or emerging area, where adopted plans and regulations would need to ensure the internal and external connectivity, a mix of uses, densities, and urban design features necessary to support alternative modes of transportation.

\section{Why Establish an MMTD?}

Establishing a successful MMTD can provide many benefits to a community and its residents. The MMTD provides an alternative to the typical disconnected, auto-dependent developments that are commonly seen throughout Florida. Shortened distances between work, home, and shopping areas promote walking and bicycling; greater emphasis on transit boosts ridership; and increased pedestrian activity heightens security. With automobile dependency reduced, expenditures that would otherwise be dedicated to building and widening




major roads can be used for sidewalks, bicycle routes, transit facilities and other improvements aimed at supporting alternative modes of transportation.

The new legislation also allows local governments in Florida to use alternative approaches to concurrency determinations (Chapter 163.3180(15)(d), F.S.). Typically, minimum level of service standards are established in local comprehensive plans based solely on automobile usage. In an MMTD, concurrency determinations may be based on multimodal performance measures that consider all of the available modes of transportation, including walking, biking, and transit.

Where minimum automobile level of service standards are exceeded by proposed developments, "local governments may issue development permits in reliance upon all planned community design capital improvements that are financially feasible over the development or redevelopment timeframe, without regard to the period of time between development or redevelopment and the scheduled construction of capital improvements" (2). This statement provides considerable flexibility in accomplishing concurrency, while allowing the intensity and type of development necessary to support multimodal objectives.

\section{Planning \& Implementation}

MMTD designation is accomplished by amending a local government comprehensive plan and accompanying future land use map, as provided in Chapter 163.3184, F.S. A proposed multimodal transportation district must be reviewed and approved by both the Department of Community Affairs (DCA) and the Florida Department of Transportation (FDOT). Local governments must demonstrate that an area qualifies as an MMTD based upon the following existing or planned future design elements defined in Chapter 163.3180(15)(b), F.S.:

- A complementary mix and range of land uses;

- An interconnected network of streets to encourage walking and bicycling, with traffic calming where desirable;

- Appropriate densities and intensities of use within walking distance of transit stops;

- Daily activities within walking distance of residences, allowing independence to persons who do not drive;

- Public uses, streets, and squares that are safe, comfortable, and attractive for the pedestrian, with adjoining buildings open to the street and with parking not interfering with pedestrian, transit, automobile, and truck travel modes.

Communities considering designating an MMTD are encouraged to review the FDOT Multimodal Transportation Districts and Areawide Quality of Service Handbook (Multimodal Handbook) and to contact the Florida Department of Transportation (FDOT) and the Department of Community Affairs (DCA) early in the process for guidance. The Handbook provides guidelines for local governments to achieve the successful designation of an MMTD. The guidelines are also used in assessing the success of a district by FDOT and DCA.

The FDOT Multimodal Handbook characterizes a "good candidate" as having "a mix of mutually supporting land uses, good multimodal access and connectivity, an interconnected




transportation network and the provision of alternative modes of transportation to the automobile" (3). Although certain elements are required for designation, many of the Multimodal Handbook's guidelines are recommendations and not rigid standards or thresholds. Flexibility is provided during the review process for proposed districts that fail to meet all applicable standards.

After the plan is amended, consistent local ordinances must be adopted to implement the new district. Local governments could elect to amend existing land development regulations either through an overlay zone, which adds new regulations onto the underlying zoning district(s), or a special district with new design standards and regulations that are tailored to the MMTD.

Table 1: Basic Criteria for a Multimodal Transportation District

\begin{tabular}{|c|c|}
\hline Land Use & $\begin{array}{l}\text { - } \quad \text { Be of sufficient size to support uses and transportation alternatives } \\
\text { - } \quad \text { Contain a variety of land uses, including both employment and residential } \\
\text { - } \quad \text { Include land uses promoting pedestrian, bicycle, and transit use }\end{array}$ \\
\hline $\begin{array}{l}\text { Appropriate } \\
\text { Density and } \\
\text { Intensity of } \\
\text { Land Uses }\end{array}$ & $\begin{array}{l}\text { - Sufficient densities to demonstrate transit ridership } \\
\text { - } \quad \text { Sufficient intensities in and around central cores } \\
\text { - } \quad \text { Sufficient intensity along major transit corridors }\end{array}$ \\
\hline $\begin{array}{l}\text { Interconnected } \\
\text { Street System }\end{array}$ & $\begin{array}{l}\text { - } \text { Adequate levels of service for bicyclists, pedestrians, and transit } \\
\text { - } \text { Appropriate numbers of connections within the street network } \\
\text { - } \text { Connected pedestrian, bicycle, and transit network } \\
\text { - } \quad \text { Convenient modal connections } \\
\text { - } \quad \text { Convenient connections to regional transportation }\end{array}$ \\
\hline Design & $\begin{array}{l}\text { - } \\
\text { - } \\
\text { - Transit oriented development within the area } \\
\text { - Shorter block length providing easier access and better quality pedestrian } \\
\text { environment }\end{array}$ \\
\hline $\begin{array}{c}\text { Additional } \\
\text { Considerations }\end{array}$ & $\begin{array}{l}\text { - Special considerations given to schools and their multimodal needs to } \\
\text { provide a safe, accessible environment for students } \\
\text { - } \quad \text { Reduction in vehicle miles of travel within the district } \\
\text { - } \quad \text { Determination of impacts on any FIHS facility }\end{array}$ \\
\hline
\end{tabular}

Source: (3).

Given the many objectives of MMTDs, it is advisable to prepare a subarea plan for each district. Subarea plans, also known in Florida as select area plans, are detailed development plans for a specific geographic area. They are generally developed with oversight of an advisory group that represents area stakeholders, and may focus on a particular neighborhood, commercial district, or high growth area.

The subarea planning process is an opportunity to carefully evaluate the characteristics of a district. The FDOT Community Impact Assessment Handbook explains how to evaluate the transportation needs of an area and the potential impacts of proposed plans on the community and its quality of life (4). The process begins with the development of a community profile to provide a baseline for understanding community mobility needs and issues. This process includes the following steps: 
- Review social and economic characteristics including demographics, growth trends, labor force, major employers and housing;

- Identify community issues and attitudes through a review of secondary sources, talk with knowledgeable persons, visits to the community and interviews with stakeholders;

- Inventory study area features including community facilities \& services, existing businesses, land use characteristics, transportation characteristics, and aesthetic and cultural resources;

- Summarize findings in a written report including a socio-economic inventory map.



Figure 1: Process for developing a community profile (4).

The community profile can be used to develop an effective long term plan for the MMTD by enhancing agency understanding of community needs and attitudes, as well as the potential social and economic impacts of various planned alternatives. For example, a community profile might reveal special needs for upgrading pedestrian facilities and crossings in certain areas, extending or modifying transit routes, enhancing street and intermodal connectivity, preserving community facilities or cultural and historic resources, and so on. From there, effective strategies can be developed for reducing or avoiding potential adverse impacts of the plan and maximizing mobility benefits.

The optional sector plan approach, created by the 1998 Florida Legislature as a pilot program in four Florida counties(Section 163.3245(6), F.S.), offers another potential opportunity for planning and implementing MMTDs (5). The program was enacted as a means for preparing a conceptual, longterm build-out overlay, and detailed specific area plans for areas of 5000 acres or more. The statute waives the development of regional impact process for approved local sector plans and requires an emphasis on urban form and the protection of regional resources and facilities. Should this program be extended for statewide use, it could be an effective means of creating a multimodal transportation district in emerging or undeveloped areas. 


\section{The Importance of Incentives}

Infill costs in urban areas can be an impediment to accomplishing the density and mix of uses that are necessary for a successful multimodal district. Statutory language encourages local governments to offer financial incentives, such as reduced impact fees, to offset the high costs of urban infill and redevelopment within an MMTD. Communities can reduce impact fees for development according to the reduction of vehicle trips per household or vehicle miles of travel expected from the development pattern planned for the district.

One area that varies transportation impact fees to reinforce alternative modes of transportation is the City of Bellevue, Washington. Bellevue varies impact fees depending upon the location and type of development (sometimes as much as $100 \%$ ), with much lower fees in the downtown area based on its high level of transit service (6). Florida communities could also look to the City of Portland, Oregon for an example of how impact fee programs could be structured to advance multimodal transportation objectives. Portland discounts impact fees (called system development charges or SDCs) for "transit-oriented" developments and also applies SDC revenues to transportation capital improvement projects that advance multimodal transportation objectives over a 10-year period (7). Qualifying criteria for eligibility for SDC expenditures of relevance to MMTDs include:

- accommodates increased density and/or in-fill re/development,

- reduces reliance on automobile usage by increasing access to alternate modes of travel,

- improves transit connections between employment centers and neighborhoods, and

- limits impacts of motor vehicles on pedestrian, bike, and transit-oriented areas.

Other incentives that can be explored are community redevelopment areas/tax increment financing districts and publicly funded improvements to area infrastructure and streetscapes. In addition, some states, including Rhode Island, New Jersey, and Maryland, have enacted Rehab Codes as a means of reducing costs associated with revitalizing older buildings in urbanized areas. Rhode Island's Rehab Code, which went into effect in May 2002, is a streamlined and user-friendly document that reduces the time, expense and unpredictability of revitalizing older buildings for residential, commercial and industrial uses (8).

The Puget Sound Regional Council also notes the following effective incentives for transit-oriented developments (6):

- Density bonuses for projects that include a certain percentage of affordable housing units. In this way, communities can help preserve affordable housing alternatives and socio-economic diversity in multimodal districts, given the tendency of such areas to gentrify with a corresponding increase in housing prices.

- Expedited development applications in exchange for density. Fast-tracking permits can help offset the high costs of infill and also help promote densification where it is desired. So often, projects that increase density have the opposite problem - permitting delays due to controversy over higher densities.

The model land development regulations in this report offer traffic impact fee offsets of varying degrees. Such offsets could be tailored to promote specific planning objectives for the MMTD. Expedited review is also offered for development proposals that advance multimodal goals within an MMTD. 


\section{Monitoring}

Monitoring the progress of an MMTD occurs biennially through a cooperative effort between DCA, a local government and technical assistance provided by FDOT (3). These reviews and reports also serve as an aide to other communities that may participate in the MMTD program. Local governments can also internally monitor the success of an MMTD by establishing performance targets that should be achieved within an MMTD by a specific planning horizon.

Recommended performance targets are provided on page 43 of the Multimodal Handbook as follows:

Table 2: Recommended Performance Targets for Multimodal Transportation Districts

\begin{tabular}{|c|c|c|c|c|}
\hline & PEDESTRIAN & TRANSIT & BICYCLE & AUTOMOBILE \\
\hline $\begin{array}{c}\text { TRANSIT- } \\
\text { ORIENTED }\end{array}$ & $\mathrm{C}$ & $\mathrm{C}$ & $\mathrm{D}$ & FIHS/LGCP* \\
\hline $\begin{array}{c}\text { NON-MOTORIZED } \\
\text { ORIENTED }\end{array}$ & $\mathrm{C}$ & $\mathrm{D}$ & $\mathrm{C}$ & FIHS/LGCP* \\
\hline
\end{tabular}

*LOS standards for facilities on the Florida Intrastate Highway System (FIHS) are established by the FDOT. LOS standards for all other roadways are established in (refer to appropriate section) of the local government comprehensive plan (LGCP).

Source: (3).

The Multimodal Handbook also includes performance measures aimed at accomplishing specific multimodal objectives to guide development in the District. These are as follows:

- $80 \%$ of all facilities contained in bicycle and pedestrian networks function at LOS C or better,

- All parcels within $1 / 4$ mile of a transit stop should be served by pedestrian facilities operating at LOS C or better,

- $80 \%$ of employees and dwelling units in a district will be located within $1 / 2$ mile of a transit stop.

Communities could establish a variety of other performance measures specific to the needs of a particular area for use in monitoring progress and guiding development towards desired outcomes. In reality, monitoring will need to occur continuously in response to development requests, to assure that the desired objectives of the MMTD are being met. In addition, the Evaluation and Appraisal process for comprehensive plans, which local governments in Florida must conduct every seven years, offers a formal opportunity to evaluate progress toward meeting MMTD objectives. The Evaluation and Appraisal report is intended to measure a community's progress in addressing major community land use planning issues through implementation of its comprehensive plan. Based on this evaluation, the report could suggest ways the MMTD should be revised to better accomplish multimodal objectives and to address changing conditions and trends. 


\section{PART II: MODEL COMPREHENSIVE PLAN AMENDMENTS}

\section{Introduction}

The following model language is intended as a guide for developing a local comprehensive plan amendment for multimodal transportation districts. The language is tailored specifically for Multimodal Transportation District(s) as they are defined in Florida law, but several of the policies could also be modified for broader application. References that appear between brackets [] in italics must be filled in by the local government.

\section{Multimodal Transportation Districts}

Objective. Establish multimodal transportation districts (MMTD) within the community where secondary priority is placed on vehicle mobility and primary priority is placed on providing a safe, comfortable and attractive environment for pedestrians and bicyclists with convenient access to transit, thereby encouraging the use of multiple modes of transportation and leading to a reduction in automobile use and vehicle miles traveled.



Policy 1. Designation Criteria. Existing areas with multimodal characteristics or proposed new multimodal developments (e.g. traditional neighborhood developments) may be designated as a Multimodal Transportation District (MMTD) in accordance with the following criteria.

1. Type of MMTD. An existing area or development plan may qualify for designation as an Urban Center, Regional Center, or Traditional Town/Village MMTD provided it generally conforms with the characteristics of that category as specified below and in Table 3:

a. Urban Center. The Urban Center MMTD shall be characterized by intense development and major employment supported by residential uses that produce a significant amount of multimodal activity because walking, bicycling, and transit are more convenient than using the automobile. This category is typically reserved for existing urban core or downtown areas.



Source: (3). 




Source: (3).

b. Regional Center. The Regional Center MMTD shall be characterized by a significant area of development that is smaller than an Urban Center and provides convenient daily retail and personal service within walking distance of surrounding residential areas. This category is typically most appropriate for new town developments and existing activity centers other than urban core areas.

c. Traditional Town or Village. The Traditional Town MMTD shall be characterized as a traditional "Main Street" community organized around a focal point with a sense of community identity. This category is typically applied to historic neighborhoods or smaller town environments with a main street.



Source: (3).

Table 3: Multimodal Transportation District Characteristics

\begin{tabular}{|c|c|c|c|}
\hline & URBAN CENTER & REGIONAL CENTER & $\begin{array}{l}\text { TRADITIONAL } \\
\text { TOWN OR } \\
\text { VILLAGE }\end{array}$ \\
\hline POPULATION & $>50,000$ & $25,000-50,000$ & $<25,000$ \\
\hline JOBS & $>50,000$ & $>5,000$ & $<5,000$ \\
\hline AREA & 10 square miles & 5 square miles & 2 square miles \\
\hline COMPACT CORE & $\begin{array}{c}\text { Community and } \\
\text { commercial services }\end{array}$ & $\begin{array}{c}\text { Community and } \\
\text { commercial services }\end{array}$ & Community services \\
\hline DENSITY & High & Mid- to High & Mid \\
\hline
\end{tabular}

Source: (3).

2. Financial Feasibility. MMTDs shall only be approved in conjunction with the approval of financially feasible plans for bicycle, pedestrian and transit systems that reduce reliance on automobiles for access and internal circulation.

3. Preservation of FIHS. Proposed MMTDs shall not significantly degrade the adopted level of service standards for facilities designated as part of the Florida Intrastate Highway System.

4. Required Design Elements. Proposed Multimodal Transportation Districts must exhibit the following community design elements, as outlined in F.S. 163.3180(15)(a-d):

a. An interconnected network of streets and paths designed to encourage walking and bicycle use, with traffic calming where desirable; 
b. A complementary mix and range of land uses, including residential, educational, recreational, and cultural;

c. Appropriate densities and intensities of land uses within walking distance of transit stops;

d. Daily activities within walking distance of residences and public uses, streets and squares that are safe, comfortable, and attractive for the pedestrian, with adjoining buildings open to the street and parking designed so as not to interfere with all transportation modes.

Policy 2. Designation of MMTD(s). In accordance with Policy 1, and the provisions of F.S. 163.3180 and the FDOT Multimodal Transportation Districts and Areawide Quality of Service Handbook (Multimodal Handbook), the [local government] hereby establishes the area(s) in Exhibit XX and identified on the Future Land Use Map as Multimodal Transportation District(s) for the purpose of promoting walking, bicycling and transit use and reducing dependence on the automobile.

Commentary: Proposed MMTD designations must be analyzed for conformance with the criteria provided in the FDOT Multimodal Transportation Districts and Areawide Quality of Service Handbook (Multimodal Handbook), and evaluated and approved by the Florida Department of Community Affairs in coordination with the Florida Department of Transportation. The designation criteria in Policy 1 are designed for consistency with F.S. 163.3180 and the Multimodal Handbook.

Policy 3. Organization of Land Uses. The [local government] shall review the Future Land Use Map and land development code in each MMTD and modify them as needed to provide for an appropriate density, intensity and mix of land uses to support multimodal transportation, and specifically to ensure:

a. a strong central core or urban center consisting of government centers, transit stations, or a town square surrounded by relatively high density/intensity residential and non-residential development;

b. a compatible mix of land uses throughout the MMTD and within individual sites and buildings that supports alternative modes of transportation and promotes activity during peak and non-peak hours;

c. proximity of shopping, services, and employment centers to each other and to the surrounding residential uses to facilitate walking and bicycling, as an alternative to driving.

Policy 4: Relationship to Major Thoroughfares. Multimodal Transportation Districts shall be planned in a manner that maximizes internal circulation and minimizes conflicts on the Florida Intrastate Highway System (FIHS) and other major arterial roadways which have the primary function of moving high volumes of statewide and regional traffic. Where such roadways are included in a Multimodal Transportation District, a minimum of two (2) safe pedestrian crossings shall be provided per mile. 




Figure 2: Recommended Location of Activity Centers Along Major Arterial Corridors (3).

Commentary: Major roadways can have a barrier effect on a multimodal district. Conversely, multimodal activity centers can cause unsafe conflicts between transportation modes, inadequate corner clearance of access points, and other safety and operational problems if they are not carefully planned and located. It is best to avoid placing activity centers so they straddle major roadway intersections. Orienting vehicular access and circulation systems away from a major arterial and onto minor roadways protects and reinforces alternative modes of transportation. Alternative modes and intermodal connections should be provided on the arterial in a manner that preserves through traffic movement. For example, consider providing bus rapid transit service on major arterials to connect activity centers. Locate transit station areas and pedestrian crossings in strategic locations so they are coordinated with the overall signal timing plan. Bus stops could be located downstream of signalized intersections to avoid conflicts with queuing and turning traffic at the road intersection. See the national Access Management Manual for further information on access management and development planning.

\section{Policy 5: Transportation Quality/Level of Service.}

1. The [local government] shall coordinate with the [local transit agency] and the MPO to apply the transit quality of service framework as found in the Second Edition of the Transit Capacity and Quality of Service Manual (TCQSM) and required as part of the MPO’s long-range transportation plan.

2. [Local government] establishes the following minimum quality/level of service standards and performance targets for transit, bicycle and pedestrian facilities and roadways within the MMTD(s) shall be as follows:

a. $80 \%$ of all the bicycle and pedestrian facilities within the MMTD network shall function at LOS C or better;

b. All parcels within $1 / 4$ mile of a transit stop should be served by pedestrian facilities operating at LOS C or better;

c. $80 \%$ of the employees and dwelling units in a district will be located within $1 / 2$ mile of a transit stop. 
Table 4: Minimum LOS Standards for Multimodal Transportation Districts

\begin{tabular}{|c|c|c|c|c|}
\hline $\begin{array}{c}\text { TRANSIT- } \\
\text { ORIENTED }\end{array}$ & PEDESTRIAN & TRANSIT & BICYCLE & AUTOMOBILE \\
\hline $\begin{array}{c}\text { NON-MOTORIZED } \\
\text { ORIENTED }\end{array}$ & $\mathrm{C}$ & $\mathrm{C}$ & $\mathrm{D}$ & FIHS/LGCP* \\
\hline
\end{tabular}

* LOS standards for facilities on the Florida Intrastate Highway System (FIHS) are established by the FDOT. LOS standards for all other roadways are established in (refer to appropriate section) of the local government comprehensive plan (LGCP).

Source: (3).

Commentary: The Areawide Quality of Service for transit, bicycle and pedestrian facilities within each MMTD can be measured in accordance with the methodology established in the Multimodal Handbook.

Policy 6: Transportation Concurrency. Transportation concurrency in the MMTD shall be evaluated based upon a financially feasible long-range capital improvements plan and program for the district, without regard to the period of time between development or redevelopment and the scheduled construction of the capital improvements.

Commentary: Rule 9J-5.0055(3)(c)7 provides that a development order or permit within a designated multimodal transportation district may be issued provided the planned community design capital improvements are included in a financially feasible long range schedule of improvements for the development or redevelopment time-frame for the district, without regard to the period of time between development or redevelopment and the scheduled construction of the capital improvements, as specified in Section 163.3180(15)(c), F.S.

Policy 7: Multimodal Street Design and Operation. The [local government] shall establish multimodal street cross-sections, design standards, and operational measures (e.g. pre-emptive signals, dedicated bus lanes, etc.) to ensure streets are safe, convenient and appealing for all modes of travel, including transit, automobiles, trucks, bicycles and pedestrians. Strategies shall include marked crosswalks, wider sidewalks, on-street parking, bus turnouts, traffic calming, raised medians, adequate drainage or other appropriate safety enhancements that reduce hazardous conflicts between modes and that are consistent with the planned functions of the roadway.

Commentary: Plans for new or reconstructed streets under the jurisdiction of the FDOT should be reviewed by the local government, the local transit agency, the bicycle pedestrian coordinator and any standing committees or other interested parties for compliance with the intent of the MMTD and other multi-modal plans.

Policy 8: Street Network and Connectivity. MMTDs shall provide a dense, interconnected network of local and collector streets that supports walking, bicycling and transit use, while avoiding excessive through traffic in residential neighborhoods, in accordance with the following:

a. The street network shall be comprised of a system of interconnected and direct routes with a connectivity index of 50 or more polygons per square mile as measured in the Multimodal Handbook.

b. For MMTDs with a street connectivity index below 50, the missing links in the street network shall be identified and eliminated where feasible through the development and capital improvement process. 
c. Each MMTD shall be subject to a maximum block (length or perimeter) requirement to advance connectivity as development and redevelopment occurs.

d. Connections of new local and collector streets and driveways with arterial streets shall conform to adopted access spacing intervals of the agency with jurisdiction.

e. The local street circulation pattern shall maximize access to individual lots and activity center destinations (e.g. schools, commercial areas, parks). At the same time, the circulation pattern shall discourage cut-through traffic in residential areas through designs such as curving roads, jogs, T-intersections, roundabouts, gateway treatments, and traffic calming techniques (e.g. chicanes, speed tables, raised intersections, on-street parking, etc).

Commentary: A maximum block length requirement ranging from 245-660 feet could be established in code, depending upon the access management needs of the affected primary or secondary roadway. Maximum block perimeter standards (e.g. 1320 feet) may be preferred as these can provide more flexibility to accommodate variations in terrain and existing buildings or barriers. The model regulations in Part III of this report call for a maximum 660 ft. block length, with exceptions for specified conditions, and include a requirement for a 20 foot wide bicycle/pedestrian easement to pass through blocks in excess of 660 feet in length.

Policy 9: Bicycle/Pedestrian Network and Connectivity. MMTDs shall provide direct bicycle and pedestrian connections within and between residential areas and supporting community facilities and services, such as shopping areas, employment centers, transit stops, neighborhood parks, and schools. The following criteria shall also apply:

a. The bicycle and pedestrian network shall each be comprised of a system of interconnected and direct routes with a connectivity index of 50 or more polygons per square mile as measured in the Multimodal Handbook.

b. For MMTDs with a connectivity index below 50, the missing links or gaps in the bicycle and pedestrian network shall be identified and eliminated where appropriate through the development and capital improvement process. Missing links may include locations between cul-de-sacs, through walls or fences, mid-block where block length exceeds 660 feet, or where bicycle pedestrian routes would otherwise be "excessively" circuitous.



Figure 3: Pedestrian Cut-Through from Cul-De-Sac to Transit Stop Along Arterial Street. 
c. Highest priority for improvements shall be given to locations with high concentrations of pedestrian activity and where connections are needed to ensure easy access between transportation modes, with particular attention to bicycle and pedestrian access to schools, transit stops and regional greenway or trail systems.



Example of Pedestrian Access from a Sidewalk to a Parking Lot.
Commentary: It is helpful to set a benchmark for eliminating existing deficiencies, such as "eliminate at least one (1) linear mile of gaps in the bicycle and pedestrian facilities network each year. In addition, request the input of the local bicycle and pedestrian coordinator and bicycle and pedestrian advisory committee on appropriate bicycle and pedestrian facilities throughout project planning for new roadway construction or reconstruction. Another way to encourage bicycle use within the MMTD is to distribute bicycle maps with the location of routes, parking areas, transit interfaces, streets to avoid and safety tips.

Policy 10: Consideration for Schools. The [local government] shall give special consideration to schools and their multimodal needs to provide a safe, accessible environment for students by giving high priority to bicycle and pedestrian facilities within a two-mile radius of all schools in both new development and redevelopment.

Commentary: The Safe Ways to School program offers detailed information for consideration. Local governments may want to establish higher multi-modal level-of-service standards for bicycle and pedestrian modes on primary routes leading to schools.

Policy 11: Consideration for Demographics. Special consideration shall be given to areas with concentrations of students, seniors, low-income families or others that are more dependent on modes other than the automobile to provide a safe, accessible environment.

Policy 12: Contributions to Multimodal Network. New developments or redevelopment projects shall contribute to providing a safe, convenient, comfortable and aesthetically pleasing transportation environment that promotes walking, cycling, and transit use. Appropriate improvements or enhancements to the multimodal network may be required as a condition of development approval, such as the following:

- Full accommodations for pedestrian access and movement, including shaded sidewalks, benches and enhanced crossings;

- Full accommodations for bicycles, including lockers, showers, and racks;

- Direct connections between the MMTD and the regional bicycle/pedestrian network; 
- Installation of shared use paths in accordance with the FDOT Bicycle Facilities Planning and Design Guidelines Handbook;

Commentary: The FDOT Bicycle Facilities Planning and Design Guidelines Handbook (Revised April 2000) defines a shared use path as "a bikeway physically separated from the motorized vehicular traffic by an open space or barrier and wither within highway right of way or within an independent alignment. Shared use paths will be used by pedestrians, skaters, and joggers as well as bicyclists."

- Well-designed accommodations for transfer of passengers at designated transit facilities;

- Preferential parking for rideshare participants;

- Well designed access for motor vehicle passenger drop-offs and pick-ups at designated transit facilities and at commercial and office development sites;

- Full accommodation for the mobility impaired, including parking spaces, sidewalks and ramps for handicapped access;

- Weather protection at transit stops.

Policy 13: Transit. The [local government] shall work with the [local transit agency] to ensure that the MMTD is well-connected via transit to major trip generators and attractors both inside and outside of the MMTD, that transit stops and waiting areas are safe and comfortable, and to enhance intermodal connections.

a. Identified needs shall be reflected in the [transit development plan (TDP)] and/or the [local government] capital improvements program and priority shall be given to funding of improvements that increase the availability, speed, frequency, duration and reliability of transit serving the MMTD.

b. The [local government] shall coordinate with the [local transit agency] regarding the provision of transit centers, super stops, and other facilities for the transfer of passengers to and from the MMTD via the regional transit system.

c. The [local government] shall coordinate with the [local transit agency] regarding the provision of benches, signage, lights, and covered or enclosed waiting areas for transit stops within the MMTD.

d. The [local government] shall coordinate with [local transit agency] regarding the provision of bicycle parking at transit stops and bicycle racks on buses as a means to interface bicycle travel with public transit.

Commentary: Policies $12 c, d$, and e above were taken from "Recommended Transit-Supportive Language and Policies for Local Government Planning Documents" by Chandra Foreman, National Center for Transit Research (CUTR 2002). Local governments may want to coordinate with the Metropolitan Planning Organization (MPO) to ensure that the provision of public transportation is considered in lieu of or as part of major transportation construction projects.


Protection should be provided for people and bicycles. 
Policy 14: Parking Management. Parking shall be limited to discourage single-occupant vehicle commuting and reinforce non-auto modes, but not so limited as to adversely impact the viability and vitality of the MMTD. Emphasis shall be on short-term parking (e.g. parking duration limits, time-ofday limits, restricted parking zones] over long-term parking in commercial areas.



Transit stop with easy access to surrounding land uses. Source: (9).
Policy 15: Limits on Parking. Maximum allowances for off-street parking spaces shall be established in the land development code for land uses within the MMTD and reviewed periodically as conditions change to ensure they continue to adequately address parking needs and the availability of transit or other non-auto modes.

Policy 16: Location and Design of OffStreet Parking. Off-street parking areas shall be located and designed in a manner that supports and does not conflict with pedestrian activity, such as to the side or rear of buildings, and shall be limited in size and scale through strategies such as shared parking, parking credits, and maximum parking limits.

Policy 17: Vehicle Trip Reduction/Transportation Demand Management. Transportation demand management strategies shall be incorporated into the transportation planning process for MMTDs to alleviate congestion. A range of techniques will be considered, such as vanpool/ridesharing programs, parking management, pricing, transit vouchers, pre-tax incentives, telework, flextime, and/or other appropriate trip reduction strategies. The local government will identify and work with other service providers, as appropriate, to implement the selected strategies.

Commentary: Some areas have a regional commuter assistance program (CAP) that can assist with the development of a transportation demand management program. In the absence of a CAP, the FDOT commuter assistance program may be contacted for assistance. Local governments could advance TDM by providing matching funds to private initiatives that support TDM, such as employer vanpool programs. This reduces the financial risk to the public in introducing new services, while providing seed money for employers to invest in their own employees' commutes by transit, vanpool, carpool, bicycling and walking.

The feasibility of establishing a transportation management association (TMA) within the MMTD could also be explored. The TMA is a public-private partnership to address local issues, foster community participation and potentially provide mobility management services. Services may include emergency guaranteed ride home programs, vanpool services, technical assistance to employers, schools and others on trip reduction strategies, circulator services, workshops and programs about safe bicycling, and so on. Funding for the TMA may be accomplished through the creation of a community improvement district, as defined by the geographic boundaries of the MMTD.

Policy 18: Building Orientation. Buildings shall be oriented to provide pedestrians and bicyclists with easy access and a visually interesting environment that reduces perceived travel distances and increases the legibility of the bicycle and pedestrian network. 
Policy 19: Design Guidelines. The [local government] shall establish architectural design guidelines appropriate for application in MMTDs by [specify date] to ensure that new construction and infill or redevelopment will contribute positively to the character and livability of the MMTD.

Policy 20: Intergovernmental Coordination. The [local government] shall coordinate with the Florida Department of Transportation, the local metropolitan planning organization, the local transit provider and other affected agencies and jurisdictions to implement land use, transportation, and parking policies that promote transportation choice and to overcome identified deficiencies in the multimodal transportation network. 


\section{PART III: MODEL LAND DEVELOPMENT REGULATIONS}

The following model regulations are intended to accompany the Florida Department of Transportation Multimodal Transportation District and Areawide Quality of Service Handbook (Multimodal Handbook). The model provides sample language and guidelines for amending local land development regulations to implement a multimodal transportation district that has been designated in the adopted local comprehensive plan. It is tied to the comprehensive plan language in the previous section of this report and is not intended to be a stand alone ordinance; nor does it address all issues that may arise within a particular context. Although the language is intended for use by local governments that have adopted an MMTD, much of the language may also be useful for promoting a multimodal transportation system within the broader community. Local governments should obtain professional planning and legal assistance when adapting this model regulatory language to fit local needs.

\section{Article I. Multimodal Transportation Districts (MMTDs)}

\section{Section 1: General Requirements}

\subsection{Intent and Purpose}

(1) The intent of this Article is to implement multimodal transportation districts (MMTDs) that have been designated within the [local government] pursuant to Chapter 163.3180(15), F.S. and the Florida Department of Transportation Multimodal Handbook, for the purpose of creating safe, comfortable and attractive environments for pedestrians and bicyclists, with convenient access to transit. Specific purposes of this Article include:

a) Establish land use, community design and transportation network guidelines and standards that facilitate walking, bicycling and transit use as an alternative to driving;

b) Establish incentives for developers to advance multimodal objectives within the MMTD.

\subsection{Relationship to the Comprehensive Plan}

Multimodal Transportation Districts shall be designated according to the minimum criteria set forth in the [local government] Comprehensive Plan and delineated on the Future Land Use Map pursuant to Chapter 163.3180(15), F.S. and the Florida Department of Transportation "Multimodal Transportation District and Areawide Quality of Service Handbook". This Article provides regulations to implement the following Goal, Objectives and Policies contained in the [local government] Comprehensive Plan: [List multimodal Goal, Objectives and Policies].

\subsection{Applicability}

(1) The provisions of this Article apply to all development proposals within areas designated as Multimodal Transportation Districts in the Comprehensive Plan, or to developments that request and are granted such designation pursuant to Chapter 163.3180(15), F.S. the [local government] Comprehensive Plan. 
(2) These regulations are intended to apply to all development including both public and private facilities within an MMTD.

(3) Inconsistencies between other sections of the land development regulations and those pertaining to the MMTD shall be superseded by the MMTD regulations.

\section{Section 2: Land Use}

\subsection{Land Use Mix Required}

(1) All development proposals shall contribute to accomplishing a mix of residential and non-residential uses as outlined in Table 5.

Table 5: Preferred Mix of Uses

\begin{tabular}{|l|c|c|}
\hline \multicolumn{1}{|c|}{ LAND USE } & EXISTING MIX & PREFERRED MIX* \\
\hline Open Space/Parks/Recreational & $\mathrm{XX} \%$ & $5-15 \%$ \\
\hline Office/Commercial/Industrial & $\mathrm{XX} \%$ & $30-70 \%$ \\
\hline Residential & $\mathrm{XX} \%$ & $20-60 \%$ \\
\hline
\end{tabular}

* Select a percentage that reflects a reasonable target for the specific MMTD.

Source: (3).

(2) Proposed developments should contribute to a mix of land uses that are compatible with the transit- and pedestrian-oriented nature of the MMTD and generally outlined in Table 6.

Table 6: Land Use Compatibility Matrix

\begin{tabular}{|l|c|c|c|}
\hline & $\begin{array}{c}\text { URBAN } \\
\text { CENTER }\end{array}$ & $\begin{array}{c}\text { REGIONAL } \\
\text { CENTER }\end{array}$ & $\begin{array}{c}\text { TOWN OR } \\
\text { VILLAGE }\end{array}$ \\
\hline Office & & & \\
\hline Center Office & & & \\
\hline Suburban Office & $\square$ & $\square$ & $\square$ \\
\hline Local Services & $\square$ & $\square$ & $\square$ \\
\hline Medical Office & & & \\
\hline Commercial & $\square$ & $\square$ & $\square$ \\
\hline Hotels & $\square$ & $\square$ & $\square$ \\
\hline Theaters & $\square$ & $\square$ & $\square$ \\
\hline Restaurants & $\square$ & $\square$ & $\square$ \\
\hline Local Shopping Centers & $\square$ & $\square$ & ------ \\
\hline Regional Shopping Centers & $\square$ & $\square$ & $\square$ \\
\hline Convenience Retail & $\square$ & $\square$ & $\square$ \\
\hline Specialty Shopping & $\square$ & $\square$ & $\square$ \\
\hline Hospitals & $\square$ & $\square$ & $\square$ \\
\hline Day Care & $\square$ & $\square$ & $\square$ \\
\hline Recreational & $\square$ & $\square$ & $\square$ \\
\hline Cultural & $\square$ & $\square$ & $\square$ \\
\hline Schools and Colleges & $\square$ & $\square$ & $\square$ \\
\hline Governmental/Institutional & $\square$ & $\square$ & $\square$ \\
\hline Light Industrial/Manufacturing & $\square$ & $\square$ & $\square$ \\
\hline Residential (mid - high density) & $\square$ & $\square$ & $\square$ \\
\hline Legend: Primary Use, Highly Desirable & $\square$ Supporting Use, Contributing
\end{tabular}

Source: Adapted from (3). 
(3) Proposed development should contribute to a mix of land uses that promote activity during peak and non-peak hours as outlined in Table 7.

Table 7: Land Uses Promoting Transit and Pedestrian Usage in Mixed-Use Areas

\begin{tabular}{|c|c|c|}
\hline Land Use & Peak & Off-Peak \\
\hline High Density Residential & - & a \\
\hline Commercial/Office & घ & \\
\hline Destination Retail & & $\square$ \\
\hline Convenience Retail & घ & - \\
\hline Entertainment & & $\square$ \\
\hline Institutional & $\square$ & ! \\
\hline Day Care & घ & \\
\hline School & घ & \\
\hline Grocery Stores & च & $\square$ \\
\hline Restaurants & घ & - \\
\hline
\end{tabular}

Source: (3).

(4) Proposed development shall enhance the appropriate density and intensity of land uses within walking distance (1/4 mile) of transit stops. Recommended residential densities are outlined in Table 8.

Table 8: Recommended Residential Densities

\begin{tabular}{|l|c|c|c|}
\hline RESIDENTIAL DENSITY & $\begin{array}{c}\text { URBAN } \\
\text { CENTER }\end{array}$ & $\begin{array}{c}\text { REGIONAL } \\
\text { CENTER }\end{array}$ & $\begin{array}{c}\text { TOWN OR } \\
\text { VILLAGE }\end{array}$ \\
\hline 0-7 Units per Acre & ----- & $\square$ & $\square$ \\
\hline 8-15 Units per Acre & $\square$ & $\square$ & \\
\hline 16-24 Units per Acre & - & $\square$ & \\
\hline 24+ Units per Acre & - & $\square$ & \\
\hline
\end{tabular}

Legend: - Primary Use, Highly Desirable $\square$ Supporting Use, Contributing

Source: (3).

(5) Proposed commercial uses should have a floor area ratio in the range of 0.5 to 1 , however not less than 0.25 .

Commentary: The floor area ratios cited above are recommended in "Accessing Transit: Design Guidelines for Florida Bus Passenger Facilities," Florida Planning and Development Lab, Department of Urban and Regional Planning, Florida State University, March 2004.

(6) Proposed development within commercial and mixed-use zones of an MMTD shall provide retail and service uses at the street level to promote a pedestrian-oriented



Retail shops on the street level with residential use above. 
(7) All proposed multi-level parking structures shall allow at least $50 \%$ of the ground-floor street frontage, excluding driveway entrances and elevators, to accommodate pedestrian-oriented uses such as retail or neighborhood services.



Parking Garage: Auto-Oriented Façade



Parking Garage: Pedestrian-Friendly Façade

Source: (9).

(8) Auto-oriented uses such as auto sales and repair, commercial parking lots, and drivethough businesses are prohibited within the MMTD.

Commentary: If a local government desires to grant some limited use of drive-through windows, the following regulation may be considered:

(9) Drive-through service windows shall be limited to the rear of mid-block buildings and locations accessed via alleys provided they do not substantially disrupt pedestrian activity or surrounding uses. In addition, drive-through service windows shall be accessible by bicyclists.

\section{Section 3: Street Network and Connectivity}

\subsection{General Requirements}

(1) The street network shall be designed to promote the overall connectivity of the system while avoiding excessive through-traffic in residential areas by including:

a) Multiple direct multi-modal connections to and between local destinations such as parks, schools, and shopping;

b) Inter-connections to multimodal transportation facilities and services within and outside the boundaries of the MMTD, including bus services, regional rail service, regional greenway and trail systems, the FIHS, and the regional aviation facilities; 
c) Modified grid systems, T-intersections, roadway jogs, and other appropriate traffic calming measures as provided in [Section 4. Traffic Calming] to discourage the use of local streets for cut-through traffic; and

d) Additions or enhancements to improve the street network connectivity index as provided in [Policy 8 of the Model Comprehensive Plan Amendments].

(2) All development plans shall contribute to developing and/or enhancing a street system that will allow access to and from the proposed development, as well as access to all existing and future development within a $1 / 4$ mile radius of the proposed development, via at least three arterial or major collector streets upon development of remaining parcels within the $1 / 4$ mile radius.



(a)



(b)

(a) Poor connectivity impedes walking, bicycling and transit use.

(b) Improved connectivity shortens local trips and improves multimodal mobility.

Figure 4: Connectivity of supporting streets (10).

\subsection{Street Network Design}

(1) All development plans shall incorporate and continue all sub-arterial streets stubbed to the boundary of the development plan by previously approved development plans or existing development. Developers required to extend collector roads may be eligible for impact fee credits where such extension is not reasonably related to the impacts of the development. The requirements of this subsection do not apply if it is demonstrated that a connection cannot be made because of the existence of one or more of the following conditions:

a) Physical conditions preclude development of the connecting street;

b) Buildings or other existing development on adjacent lands, including previously subdivided but vacant lots or parcels, physically preclude a connection now or in the future, considering the potential for redevelopment.

(2) The street network within development plans shall provide for future public street connections to adjacent developable or redevelopable parcels, and shall include block lengths not in excess of 660 feet, except where additional spacing is required in conformance with FDOT or [local government] access management standards and unless the developer demonstrates that a block length must be greater due to the existence of one or more of the following conditions: 
a) Physical conditions (e.g. topography), buildings or other existing development on adjacent lands physically preclude a block length 660 feet or less; or

b) An existing public street terminating at the boundary of the development site, has a block length exceeding 660 feet, or is situated such that the extension of the street(s) into the development site would create a block length exceeding 660 feet. In such cases, every effort shall be made to accomplish reasonable block lengths to maintain walkability.

(3) Proposed office and commercial development plans for sites abutting an arterial or major collector street must include internal vehicle connections from the subject development site to each adjacent site, where applicable. Exceptions may be provided where abutting uses are clearly incompatible or where physical conditions or existing development on adjacent sites precludes such connection now or in the future considering the potential for redevelopment. Development plans shall include joint use driveways with adjacent sites wherever feasible.


Figure 5: Cross-Access Corridors (10).

Commentary: For further information on access management policies and regulations see CUTR/FDOT Model Land Development Regulations that Support Access Management for Florida Cities and Counties, and visit the national access management website at www.accessmanagement.gov.

(4) Development plans shall provide or enhance a continuous service drive or alley extending the entire length of each block where it contributes to the street network. Where alleys have been vacated, development plans shall establish new alleys. Alleys shall be developed according to the following criteria:

a) Maintain a right-of-way width of $[X X]$ feet, and a pavement width of no more than $[X X]$ feet;

b) Differentiate the alley from through streets and sidewalks through the use of paving materials;

c) Provide a low street wall between the alley and the parking area and a landscaped strip inside of the wall.

Commentary: Land Design Innovations, Inc. suggests that "...alleys contribute to making the primary storefronts and streetscape a more pleasant environment by removing the necessary service and delivery areas to the rear of the site." 
(5) All cul-de-sacs shall be designed with a turnaround in accordance with [local ordinance section] and shall be no more than $[X X]$ feet in length as measured from the centerline of the intersecting street to the radius point of the cul-de-sac.

Commentary: In order to maintain bicycle and pedestrian mobility within developments having one or more block lengths in excess of 660 feet or cul-de-sacs, bicycle/pedestrian easements should be provided as detailed in Sections 7 and 8 of these regulations.

\section{Section 4: Traffic Calming}

\subsection{Local and Collector Streets}

(1) Collector and local streets shall include one or more of the following traffic calming measures to improve conditions for cyclists and pedestrians by altering driver behavior to reduce vehicle speed and traffic volume:

a) Volume control measures such as half, partial or one-way closures, diagonal deviators, median barriers, or forced turn islands;

b) Vertical speed control measures such as speed tables and raised intersections;

c) Horizontal speed controls such as mini-traffic circles, roundabouts, lateral shifts, chicanes, and realigned intersections;

d) Cartway narrowing such as neckdowns, gateways, chokers, and center island narrowings; and

e) Other measures such as on-street parking and marked and designated bike lanes.

(2) New or reconstructed non-FIHS arterial and collector streets with more than three travel lanes shall include a landscaped median and appropriate design measures (e.g. neckdowns, pavement markings, etc.) to clearly delineate pedestrian crossing locations and improve conditions for crossing pedestrians.



A traffic-calming measure that improves the pedestrian environment by slowing traffic. Source: (11). 


\section{Section 5: Parking}

Commentary: The treatment of parking is a key element of the MMTD. Parking supply should be minimized to discourage vehicle use while encouraging transit, bicycle, and pedestrian use. When transit is available in close proximity to a proposed development, the need for off-street parking may be significantly reduced. Furthermore, offering parking credits to future development may encourage transit ridership. A trend in current practice is to establish maximum parking requirements as a means of minimizing single-occupancy vehicle use. These parking requirements are intended to supplement other local parking requirements particularly regarding the number of parking spaces for specific land uses and landscaping.

\subsection{General Requirements}

(1) New developments shall provide no more than the minimum number of parking spaces required for the proposed land use by the underlying zoning district. The following shall also apply:

a) On-street parking spaces on the right-of-way between the two side lot lines of the site may be counted to satisfy the minimum off-street parking requirements.

b) Carpool/Vanpool Parking: New commercial and industrial developments with 20 or more employee parking spaces shall designate at least 5 percent of the employee parking spaces for carpool or vanpool parking. Employee carpool and vanpool parking shall be located closer to the building entrance or the employee entrance than other employee parking with the exception of handicap parking. The carpool/vanpool spaces shall be clearly marked "Reserved-Carpool/Vanpool Only.”

\subsection{Parking Credits}

(1) New development may be eligible for parking credits in exchange for transit facility placement, bicycle facilities, and/or monetary contribution toward public parking in accordance with the following criteria:

a) The minimum parking requirement may be reduced by 10 percent if an adequate sheltered transit stop and related transit amenities are provided within the development.

b) The minimum parking requirement may be reduced by up to 50 percent when the applicant can demonstrate, in a parking-traffic study prepared by a traffic engineer, that both of the following conditions exist:

i) The use of alternative modes of transportation, including transit, bicycles, and walking, and/or special characteristics of the customer, client, employee or resident population will reduce expected vehicle use and parking space demand for this development, as compared to standard Institute of Transportation Engineers vehicle trip generation rates and minimum [local government] parking requirements.

ii) A Transportation Demand Management (TDM) Program has been approved by the [local government] that contains strategies for reducing vehicle use 
and parking demand generated by the development and establishes benchmarks by which the program's effectiveness will be measured biannually.

\subsection{Shared Parking}

(1) Where it can be demonstrated that the demand for parking of the combined uses of two (2) or more buildings can be satisfied with the shared and jointly accessible off-street parking available to those buildings, then a special exception to these parking requirements may be granted by the [local government] to satisfy the minimum parking requirements pursuant to the following conditions:

a) The joint use of required facilities at different times may be allowed provided all of the following exist:

i) The applicant shows there will be no substantial conflict in the principal operating hours of the buildings or uses for which the joint parking use is proposed.

ii) The parking facility will be within $1 / 4$ mile of buildings or uses it will serve.

iii) The parties involved in the joint parking facility agree to the joint use arrangement in a legal document that has been approved by the [local government] attorney and recorded in the [County of record] with a copy filed with the [local government permits office].

(2) The simultaneous joint use of required facilities may be allowed provided all of the following exist:

a) No more than two (2) uses under separate ownership or occupancy shall be involved.

b) The uses will occur on the same development site.

c) It can be reasonably anticipated that a number of customers or clients will be served.

Commentary: Shared parking can be used to significantly reduce the amount of parking areas in a multimodal district. Shared parking arrangements between uses is most appropriate in areas where: a specific parking problem exists; land values and parking facility costs are high; clustered development is desired; and traffic congestion or vehicle pollution is a significant problem and adding pavement is undesirable. The potential for shared parking is particularly high in mixed used districts.

\subsection{Fee in lieu of parking}

(1) An in-lieu parking fee may be submitted to the city for each required parking space that is not provided on site. The in-lieu parking fee shall be determined annually by the [local government] based on current land and construction costs. There is hereby created a special fund within the Office of the Treasurer-Controller into which in-lieu fees shall be deposited to be used only for the construction of public parking facilities. 


\subsection{Parking Lot Location and Size}

(1) To minimize the impact of large expanses of parking on the pedestrian environment, parking spaces shall be located to the rear and sides of buildings wherever feasible. No off-street parking shall be located between the front façade of any building(s) and the primary adjacent street.

(2) Auto parking and maneuvering areas shall not be located between a primary building entrance and an abutting minor arterial or collector street, except where the applicant has demonstrated that no other alternative is available.

(3) Auto parking lots and maneuvering areas located to the side of a building cannot occupy more than $50 \%$ of a site’s frontage onto a minor arterial or collector street.

(4) Wherever possible, auto parking lots and maneuvering areas on corner lots should not be located adjacent to intersections.

(5) Individual parking areas may be no larger than [XX square feet in size]. Separation between individual parking areas may be achieved by the placement of internal accessways.

(6) Bicycle parking facilities (bike racks) shall be provided in all vehicle parking lots as provided in [Section 8.2].

\section{Section 6: Transit Facilities}

(1) The following types of developments located along a transit route may be required to construct transit stops at the discretion of the [local government] or in collaboration with [local transit agency]:

a) Residential developments having an average automobile peak hour trip rate of [25 trips or greater].

b) Commercial and industrial developments other than office developments, having an average automobile peak hour trip rate of [100 trips or greater]. Office developments having an average peak hour trip rate of [50 trips or greater].

c) Institutional uses and public facilities, including churches, hospitals, middle schools, high schools, universities and colleges, public parks (other than neighborhood parks), libraries, post offices, and other institutional and public facilities having an average automobile peak hour trip rate of [100 trips or greater].

(2) Transit stop design shall be a clearly defined waiting area for transit riders, open to the public at large and equipped with amenities for bicyclists and pedestrians including adequate lighting, benches, weather protection, system information, maps, trash bins, bicycle parking, and a land pad accessible to a disabled person. Plans shall include lifetime maintenance plans for the facility. 




This transit stop provides many amenities. Source: (9).

(3) New buildings at or near transit stops shall provide for convenient pedestrian access to the transit stop by providing walkways connecting the new building entrances to sidewalks accessing the transit stop.

\section{Section 7: $\quad$ Sidewalks and Pedestrian Facilities}

Commentary: Proposed pedestrian and bicycle facilities should be coordinated with the local government bicycle/pedestrian coordinator, any bicycle/pedestrian advisory committee, and adopted bicycle or pedestrian facilities plan.

\subsection{General Requirements}

(1) New development shall provide safe and convenient facilities for pedestrians that are reasonably free from hazards and high levels of automobile traffic, and provide a reasonable and direct route of travel between destinations. This section shall apply to any new development that creates a new building entrance(s). Alteration or changes in use that do not involve any creation of a new building entrance are not subject to the provisions of this section.

Commentary: This section applies to any new development that creates a new building entrance; however, the local government could apply this based on a development size instead.

(2) Pedestrian facilities shall be provided on any new or reconstructed streets in accordance with the Florida Pedestrian Facilities Planning and Design Handbook.

(3) Pedestrian facilities shall be designed with security considerations including street lighting, bushes no greater than two (2) feet in height, and tree branches no lower than six (6) feet in height. To provide clear visibility of pedestrians approaching intersection crosswalks at night, the approaches to and all street corners should be well-illuminated. 
All intersection lighting should illuminate the crossing and waiting areas and/or create backlighting to make the pedestrian silhouette clearly visible on the approach.

(4) Pedestrian facilities shall include shade trees where possible.

\subsection{Pedestrian Connections}

(1) A sidewalk shall be provided between all new building entrances and all streets adjacent to the development site. The sidewalk shall provide a direct connection to existing public right-of-way and public sidewalks or transit stops.

(2) A sidewalk shall be provided between any new building entrance and all other new or existing building entrances on the same development site. Entrances used for loading and unloading freight are not subject to this standard. Internal pedestrian paths provided in conformance with this subsection shall provide weather protection features such as awnings or arcades within 30 feet of all customer entrances.

(3) A sidewalk shall be provided immediately adjacent to the exterior wall of a new building greater than 100 feet in length when the wall is located next to a street or parking lot. A pedestrian path shall also be provided along the entire length of the wall when the public entrance is located in that area. Exceptions to this standard include:

a) If the edge of the building is within 20 feet of a public sidewalk and the building entrance is connected to the public sidewalk by an on-site pedestrian facility.

b) If the edge of the building is bordered by a perimeter of landscaping that does not exceed 30 feet in width and an on-site pedestrian facility is constructed at the edge of the landscaped area.

(4) A 20-foot wide bicycle/pedestrian easement shall be provided to connect cul-de-sacs, or to pass through blocks in excess of 660 feet.

(5) Where needed for purposes of traffic safety or access to nearby schools, playgrounds, public parks, trails, shopping facilities, or other community facilities, new developments may be required to dedicate a public right of way for bicycles and pedestrians, not less than 20 feet in width.

Commentary: "Nearby" means uses within 1/4 mile that can reasonably be expected to be used by pedestrians and bicyclists. A local government can also go further and require improvements to existing unimproved public accessways on properties adjacent to the development, provided the local government makes findings to demonstrate consistency with constitutional requirements. Said improvements to unimproved public accessways shall connect to the closest public street or developed accessway.

(6) Pedestrian access points at property edges and to adjacent lots shall be coordinated with existing development to provide pedestrian circulation between developments.

(7) All on-site pedestrian walkways located in vehicle use areas shall be distinguished from driving surfaces through the use of durable, low maintenance smooth surface materials to enhance pedestrian safety and comfort, as well as the attractiveness of the walkways. 
(8) All non-residential buildings set back [fill in number] feet or more from the public right-of-way shall provide for direct pedestrian access from the building to buildings on adjacent lots.

Commentary: This code language was adapted from "Wilmapco Mobility Friendly Design Standards" November 1997, Wilmington Area Planning Council where they recommended 100 feet as the standard.

(9) Within multi-family residential development with three (3) or more units, on-site pedestrian facilities shall be constructed in the following locations:

a) From every unit to all other units within the residential development.

b) From every unit to all laundry, recreation and other community facilities in the residential development

c) From every building located within 40 feet of a public or private street to the street right-of-way line.

\subsection{Accessible Pedestrian Facilities}

(1) Americans with Disabilities Act (ADA). To aid in the independent mobility of people who cannot drive, special accommodations should be provided in accordance with the ADA Accessibility Guidelines for Buildings and Facilities (http://www.accessboard.gov/adaag/html/adaag.htm).

Commentary: Types of improvements to aid in mobility as outlined in "Walkable Communities: Twelve Steps for an Effective Program, " include:

- Two (2) curb ramps should be constructed on each street corner.

- One (1) curb ramps should be constructed at each side of marked mid-block crossings. Or, as an alternative treatment, the crosswalk area should be raised to curb height.

- When pedestrian demand signals are used independent call poles should be appropriately placed at the top of each ramp on all signalized intersections.

- All corners should have adequate sight triangle and sufficient depth for controller box, signal pole and other hardware to be located out of the walk zone. Audio/tactile pedestrian systems should be used in areas with large elder and disabled populations.

- Minimum walk speed, sidewalk cross slopes, grades, drainage inlets and minimum widths should be considered in constructing new and retrofitting existing walkways.

\section{Section 8: Bicycle Facilities}

Commentary: Designation criteria for an MMTD assumes that some bicycle facilities, particularly bicycle lanes, already exist within the District boundaries, however, the model regulations below include some basic requirements that may already be found in the land development regulations. In addition, proposed bicycle facilities should be coordinated with the local government bicycle coordinator, any bicycle advisory committee and the Bicycle Facilities Plan. 


\subsection{Bicycle Lanes}

(1) Bicycle lanes shall be provided on new or reconstructed arterials and major collector roadways within the MMTD in accordance with the FDOT Bicycle Facilities Planning and Design Guidelines (Revised April 2002).

(2) Restriping of arterial or major collector roadways under [local government] jurisdiction within the MMTD shall be considered any time the facility is scheduled for resurfacing allowing for a safe, dedicated space for bicycle travel.



A striped bicycle lane provides a safe travel lane for bicyclists. Source: (12).

Commentary: According to Dwight Kingsbury, FDOT, "Pedestrian and bicycle facilities must be given full consideration on all proposed projects including Resurfacing, Restoration and Rehabilitation (RRR), safety, and traffic operation projects. Their inclusion on intersection reconstruction projects is particularly important as these may be excepted out of later roadway projects. Where an existing route for bicyclists is present it shall be maintained... project records must support and document why facilities were not included, " if they indeed were not. If right-of-way is constrained, the local government may consider reducing motor vehicle travel lane width to $11^{\prime}$ - resulting in a traffic calming effect. Another consideration may be to provide separate bicycle paths or even bicycle boulevards on parallel streets.

\subsection{Bicycle Boulevards}

Commentary: The FDOT Bicycle Facilities Planning and Design Guidelines Handbook defines a bicycle boulevard as "a system of roadways and connections between neighborhoods or areas in a community that forms a bicycling throughway, but discourages through and higher speed motor vehicle movement." Bicycle boulevards are bicycle priority streets where people can feel safe bicycling, even if they do not feel comfortable bicycling in traffic on ordinary streets. They are intended to have low traffic volumes, slow traffic speeds, and clear signage indicating that priority is given to bicycle traffic.

(1) Installation of a Bicycle Boulevard may be required within residential developments that meet the following conditions:

a) Existing low vehicle volumes;

b) Very little commercial frontage;

c) Roadway is parallel to a major arterial or a high-traffic collector street (within approximately 0.25 mile);

d) Not a transit or truck route;

e) Roadway is reasonably continuous, i.e. it extends over at least [two miles]; it should have few jogs with main segments at least 0.5 mile long. 
(2) The [local government] may require the following treatments on a residential or local street that has been designated as a bicycle boulevard to provide a safe and convenient circulation system for bicycles:

a) Traffic control devices so that bicyclists on bike routes can easily cross major streets and arterials;

b) STOP signs are positioned so that the bicycle boulevard has the right of way in appropriate locations;

c) Traffic calming measures, such as traffic circles or semi-diverters, in selected locations to ensure that motor vehicles do not divert to the bicycle boulevard;

d) Forced right-turns along bicycle boulevards or other locations to discourage nonlocal motor vehicle traffic from using the roadway in question. A sign shall be placed at intersections indicating that cars must turn right, but bicyclists may proceed straight.

\subsection{Bicycle Parking}

(1) Bicycle racks shall be located in convenient, visible, well-lit areas, with easy access, near main entrances. The racks should not interfere with pedestrian traffic and should be protected from potential damage by motor vehicles. They may be located within the public right-of-way with [local government] approval. The following requirements shall also apply:

a) All vehicle parking facilities containing less than ten parking spaces shall provide one bicycle rack with no less than four (4) spaces (two high-quality inverted "U” racks).

b) For vehicle parking facilities containing more than ten parking spaces the applicant shall provide one bicycle rack with no less than four spaces plus two bicycle parking spaces for each additional ten parking spaces in the lot. No more than 20 bicycle parking spaces shall be required in any one parking facility.

c) One vehicle parking space may be eliminated for each four spaces of bicycle parking provided.

(2) The [local government] and other affected agencies shall provide bicycle parking facilities at public uses such as schools, city hall, transit stations, park-and-ride lots, recreation facilities and libraries in accordance with the above



The standard inverted $U$ type bike rack supports the bike frame at two locations and allows users to secure their bikes with either a cable or $\mathrm{U}$ type lock. Source: (13). standards. 


\section{Section 9: Amenities and Design}

\subsection{Pedestrian Amenities and Community Spaces}

(1) All development plans shall contribute to the establishment or enhancement of community and public spaces by providing a space where at least two of the following: patio-seating area, pedestrian plaza with benches, covered playground area, kiosk area, water feature, clock tower or other similar focal feature or amenity. Any such area shall have direct access to the public sidewalk network and be placed in a visible location that is convenient for use as a public gathering area. The review authority may find compliance with this standard if the proposed pedestrian amenities and community spaces are incorporated as part of the shopping street. Examples include wider sidewalks, special paving, ornamental lighting, planters, public benches and seating walls, and public art.

\subsection{Building Orientation}

(1) All buildings on the site must be oriented to either a public street, a private drive, or a shopping street. The building orientation standard is met when the building is placed within the maximum setback established for the zone. The maximum setback may be exceeded if the area between the building and the street or private drive is landscaped or is an enhanced pedestrian space.

(2) Private drives used to meet building orientation standards must incorporate street design elements. When private drives are used, the setback is measured from the back of the sidewalk.

(3) On all buildings that meet the building orientation standard, building entries must be in compliance with this code.

Commentary: In Portland, Oregon's publication, "Planning and Design for Transit Handbook: Guidelines for Implementing Transit Supportive Development," non-residential buildings can be placed no more than 15-feet from the sidewalk and residential projects may have distinguishable front yards for privacy while engaging the street with windows and porches.

\subsection{Exterior Wall Articulation, Facades, and Ground Floor Windows}

(1) Exterior building walls shall not continue along an uninterrupted plane for more than 100 feet. An uninterrupted plane is a wall that has no variation in exterior surface along its length. Except for building walls facing an alley, ground floor facades 100 feet or greater in length, measured horizontally, shall incorporate wall plane projections or recesses having a depth of at least three (3) percent of the length of the facade and extending at least 20 percent of the length of the facade.

(2) Ground floor facades that face streets adjacent to the development site shall have arcades, colonnades, display windows, entry areas, awnings, or other such features along no less than 50 percent of their horizontal length. 
(3) Except for building walls facing an alley, ground floor walls shall contain windows (as stated below) at the ground level. The windows may extend a maximum sill height of four (4) feet above finished grade to any head height. The portion of window area meeting this standard is from the sill (bottom edge) to the head (top edge) including portions up to nine (9) feet above the finished grade. Alcoves, entryways, and extruding portions of the wall shall be treated by measuring through such areas as though along the flat wall of a building. Solid walls are prohibited along street frontages. This standard does not apply to parking structures.

(4) General Standard. The windows in any walls that require windows shall occupy at least 50 percent of the length and 25 percent of the ground floor wall area. Required window areas shall be either windows that allow views into working areas or lobbies, pedestrian entrances, or display windows. The bottom of the windows shall be no more than 4 feet above the finished grade.

(5) Corner Lots. On corner lots, the general ground floor window standard stated in subsection (c) must be met on one street frontage only. On the other street(s), the requirement is $1 / 2$ of the general standard. The applicant may choose on which street to apply the general standard.



Interesting facades contribute to this pedestrianfriendly area. Source: (14).

\section{Section 10: Application for Development in MMTDs}

(1) Any property owner who proposes to develop or redevelop land in an MMTD shall contact the reviewing jurisdiction to schedule a pre-application conference during which the applicant will be advised on applicable procedures and requirements.

(2) The development application shall include the following information and supporting documentation in the development or plat application:

a) A legal description of the relevant parcel of land, including a separate description of the portion that lies within the MMTD, if applicable;

b) A statement of how the applicant proposes to subdivide or develop the affected property, including a plat or a site plan map at a scale sufficient to show the building location, access connections, street network and bicycle/pedestrian circulation, open space, parking, amenities and any other matter as may be required by the [local government] land development code;

c) A statement of how the proposed development is planned and designed to be consistent with the objectives and policies of the MMTD;

d) Requests, if any, for a variance from the provisions of [this Article]. 
(3) Upon receiving the development or plat application, staff shall review the proposal and produce a written report for consideration by the [local government Development Review Committee] containing staff recommendations regarding the application including all supporting findings and conclusions regarding the consistency of the proposed project with the MMTD objectives and policies and proposed conditions of approval. The report may recommend one or more of the following:

a) Approval of the development as proposed, with or without conditions;

b) Denial of the development as proposed;

c) Modification of the proposed development and the issuance of a development permit for the development as modified, with or without conditions.

(4) Upon consideration of the staff report, the [local government development review committee] shall issue a final determination. Appeals to the determination of the [local government development review committee] shall be addressed in accordance with [local government code].

Commentary: Local governments should strive to make a streamlined development approval process to garner the cooperation of the development community.

\section{Section 11: Incentives}

(1) Expedited Development Review. Development applications within the MMTD shall be entitled to an Expedited Development Review Process. The Expedited Development Review Process entitles an applicant to be placed on a priority list, established by the [local government official]. Expedited review is on a first-come, first-served basis of priority applications. The applicant must submit a technically complete application in order to be placed on the priority list for expedited development review.

(2) Traffic Impact Fees. A reduction in the traffic impact fee for developments within the MMTD may be granted pursuant to this section with the implementation and maintenance of the corresponding action in Table 9. 
Table 9. Traffic Impact Fee (TIF) Reduction

\begin{tabular}{|c|c|}
\hline ACTION & $\begin{array}{l}\text { TIF } \\
\text { REDUCTION }\end{array}$ \\
\hline Development within the MMTD* & $2 \%$ \\
\hline Construction of on-site but off road internal pedestrian/bicycle network & $2 \%$ \\
\hline $\begin{array}{l}\text { Construction of direct walkway connections to the nearest arterial for non-abutting } \\
\text { developments }\end{array}$ & $3 \%$ \\
\hline $\begin{array}{l}\text { Direct pedestrian/bicycle connection to destination activity (such as a commercial/retail } \\
\text { facility, park, or school) if residential development, or to origin activity (such as a } \\
\text { residential area) if commercial/retail facility }\end{array}$ & $3 \%$ \\
\hline $\begin{array}{l}\text { Installation of on-site sheltered transit stop (with current or planned service or bus stop } \\
\text { within } 1 / 4 \text { mile of site with adequate walkways if approved by local government transit } \\
\text { agency) }\end{array}$ & $3 \%$ \\
\hline Installation of one secure bike parking space per 10 vehicular parking stalls & $1 \%$ \\
\hline $\begin{array}{l}\text { Connection to existing or future regional shared use path (either } 1 \% \text { directly, or by } \\
\text { existing, safe access) }\end{array}$ & $1 \%$ \\
\hline Development of a trip reduction plan to be implemented by property management & $1 \%$ \\
\hline $\begin{array}{l}\text { Designation of ten (10) percent of all non-residential parking as carpool/vanpool parking } \\
\text { facilities if located in a manner maximizing accessibility subject to ADA requirements }{ }^{* *}\end{array}$ & $1 \%$ \\
\hline
\end{tabular}

* Automatic reduction for developing within MMTD and compliance with the provisions of this Ordinance.

** Requires regular maintenance.

Source: (15).

Commentary: These incentives were primarily derived from APA's PAS Report \#468, "Creating Transit-Supportive Land Use Regulations" including specific ordinance language from Vancouver, Washington and Clark County, Washington. Percentages provided in Table 5 are for example only and should be modified to reflect the relative priority of issues in the MMTD. 


\section{PART IV: REFERENCES \& BIBLIOGRAPHY}

\section{References}

1. Chapter 163.3180(15)(a). FL, Florida Statutes.

2. Chapter 163.3180(15)(c). FL, Florida Statutes.

3. Florida Department of Transportation. Multimodal Transportation Districts and Multimodal Areawide Quality of Service Handbook. November 2003.

4. Florida Department of Transportation. Community Impact Assessment Handbook. 2000.

5. $\quad$ http://www.dca.state.fl.us/fdcp/DCP/sectorplans/Optsectpln.htm

6. Puget Sound Regional Council. Creating Transit Station Communities in the Central Puget Sound Region: A Transit-Oriented Development Workbook. 1999.

7. Henderson, Young and Company. Transportation System Development Charge Rate Study: Final Report. City of Portland, Oregon. June 11, 1997.

8. $\quad$ http://www.rbfc.state.ri.us

9. $\quad$ Central Florida Mobility Design Manual. Lynx. 2000.

10. Access Management Manual. Transportation Research Board. 2003.

11. A Review of Pedestrian Safety Research in the United States and Abroad. FHWA No. RD03-042. January 2004.

12. Dan Burden. www.pedbikeimages.org.

13. Rules and Regulations for Bicycle Parking Areas in Denver. 1998.

14. Upper Arlington Online Community Directory. www.uasupersite.com.

15. PAS Report \#468, Creating Transit-Supportive Land Use Regulations. American Planning Association. 1996. 


\section{Bibliography}

ADA. Accessibility Guidelines for Buildings and Facilities. http://www.accessboard.gov/adaag/html/adaag.htm.

Beyard, Michael D. and Michael Pawlukiewicz. Ten Principles for Reinventing America's Suburban Strips. Washington, DC: Urban Land Institute. 2001.

Board of Commissioners, Gwinnet County, Lawrenceville, GA. Resolution to Amend the 1985 Zoning Resolution. October 22, 2002.

Board of County Commissioners, Martin County, FL. Ordinance to Adopt Article 4, Section 4.19, Roadway Design of the Martin County Land Development Regulations. 1999.

Brich, Stephen C. and Lester A. Hoel. Multimodal Transportation Planning in Virginia: Past Practices and New Opportunities. Technical Assistance Report, VTRC 95-TAR1. Charlottesville: Virginia Transportation Research Council and Federal Highway Administration. 1994.

Burden, Dan. Street Design Guidelines for Healthy Neighborhoods. Center for Livable Communities. January, 1999.

Center for Urban Transportation Research/Florida Department of Transportation. Model Land Development and Subdivision Regulations that Support Access Management for Florida Cities and Counties. 1994.

Center for Urban Transportation Research/Florida Department of Transportation. Community Impact Assessment Handbook. 2000.

Chesapeake City. User's Manual. Chesapeake City, Maryland. 1998.

City of Austin, TX. Downtown Austin Design Guidelines. Design Commission. May, 2000.

City of Cambridge, MA. Zoning Ordinance. Article 14.000, Mixed Use Development District; Cambridge Center. Undated.

City of Deland, FL. Comprehensive Plan.

City of Destin, FL. Comprehensive Plan.

City of Eugene, Oregon. Land Use Regulations, Ordinance Number 20224, May 29, 2001.

City of Federal Way, WA. Public Works Development Standards, June 2001.

City of Fort Collins/Community Planning and Environmental Services. Design Standards and Guidelines for Large Retail Establishments. 1995.

City of Fort Collins Planning Department/Cityscape Urban Design. Neighborhood Convenience Shopping Centers: Policies, Guidelines and Requirements for Design and Location. 1988.

City of Fort Collins, CO. Fort Collins Land Use Code, Section 3.6.3 (E). 
City of Fort Collins, CO. Fort Collins Comprehensive Plan. February 18, 1997.

City of Gainesville, FL. 2020 Long Range Transportation Plan.

City of Gainesville, FL. Transportation Mobility Element. Goals, Objectives, Policies. August 12, 2002.

City of Hercules, California. Regulating Code for the Central Hercules Plan. July 16, 2001.

City of Lakeland, Florida. Dixieland CRA Design Guidelines (Draft). Land Design Innovations, Inc. December 2003.

City of Orlando, FL. Southeast Orlando Sector Plan: Development Guidelines and Standards. Circulation Guidelines and Standards. 1998.

City of Palo Alto. Section 18.43.040.

City of Redmond. Redmond Development Code, Sec. 20C.20.150(20)(b), December 1993.

City of San Diego, CA. San Diego Development Regulations, Ch. 14, Sec. 141.1027(a), June 30, 1994.

City of Seattle, Washington. Comprehensive Plan. Northgate Area Update Plan Policies. Department of Planning and Development.

City of Seattle, Washington. Comprehensive Plan. Transportation Element. January, 2003.

City of Seattle, Washington. Municipal Code. Chapter 23.48, Seattle Cascade Mixed.

Clark County Code. WA. Title 18 “Zoning”; Mixed-use district (MX), Section 18.320.070 (L)(1). January 1995.

Davidson, Michael and Fay Dolnick. Parking Standards. Chicago: American Planning Association. 2002.

Dixon, Karen K., Wayne A Sarasua, Janice Daniel, George D. Mazur. Tool for Rural and Statewide Multimodal Transportation Planning. Journal of Computing in Civil Engineering, 15(4), pp. 275284. 2001.

Ewing, Reid H. Pedestrian- and Transit-friendly Design: A Primer for Smart Growth. Washington, DC: Smart Growth Network. 1999.

Ewing, Reid H. Asking Transit Users About Transit-oriented Design. Transportation Research Record, No. 1735. Washington, DC: National Academy Press, pp. 19-24. 2000.

Ewing, Reid H. Impediments to Context-sensitive Main Street Design. Transportation Quarterly, 56(4), p. 51-64. 2002.

Ewing, Reid H./Florida Department of Community Affairs. Transportation \& Land Use Innovations; When You Can't Pave Your Way Out of Congestion. 1997. 
Ewing, Reid H./Joint Center for Environmental and Urban Problems/Florida Department of Transportation. Pedestrian- and Transit-Friendly Design. 1996.

Ewing, Reid H./Joint Center for Environmental and Urban Problems/Florida Department of Community Affairs. Best Development Practices: Doing the Right Thing and Making Money at the Same Time. 1996.

Florida Department of Transportation, Systems Planning Office. Multimodal Transportation Districts and Areawide Quality of Service Handbook. 2004.

Florida Department of Transportation, District 4. Neighborhood Connectivity: Literature Review \& Case Studies. July, 2003.

Florida Department of Transportation. Bicycle Facilities Planning and Design Guidelines Handbook. Revised April 2000.

Florida Department of Transportation. Walkable Communities: Twelve Steps for an Effective Program. 1995.

Florida Department of Transportation. Second Edition of the Transit Capacity and Quality of Service Manual (TCQSM).

Florida Planning and Development Lab/Florida Department of Transportation. Accessing Transit: Design Guidelines for Florida Bus Passenger Facilities. March 2004.

Georgia Regional Transportation Authority. Land Use Implementation Best Practices. Northern SubArea Study \& GA 400 Corridor Analysis. December 2003.

Gildemeister, Morris and Fred P. Tanzer. Multimodal Transportation Approaches in Minnesota. Transportation Research Record, No. 1305, Washington, DC: National Academy Press, pp. 264268. 1991.

Guttenplan, Martin, Bruce W Landis, Linda Crider, and Douglas S. McLeod. Multimodal Level-ofService Analysis at Planning Level. Transportation Research Record, No. 1776. Washington, DC: National Academy Press, pp. 151-159. 2001

Hauser, Ed and Amy R. Breese. Partnerships for Multimodal Transportation Planning. Transportation Research Record. No. 1552. Washington, DC: National Academy Press, pp. 57-66. 1996.

Mays, Vernon. Fairhaven Arrival - The former headquarters of a fishery company in Bellingham, Washington, becomes a multimodal transportation hub. Historic Preservation, 47(6), pp. 32-38. 1995

Martin County, FL. Land Development Regulations, Article 4, Section 4:19, Roadway Design and Access Management.

Mazur, George D., Wayne Sarasua, and Janice Daniel. Multimodal Transportation Planning Tool for Rural Areas in Georgia. Transportation Research Record, No. 1552. Washington, DC: National Academy Press, pp. 48-57. 1996. 
Metro. Creating Livable Streets: Street Design Guidelines for 2040. Portland, OR: Metro. 1997.

Montgomery County, MD. Montgomery County Code. Article 59-E. Off-Street Parking and Loading. 2003. http://www.montgomerycountymd.gov.

Morris, Marya. Creating Transit-Supportive Land-Use Regulations. American Planning Association Planning Advisory Service Report Number 468. December 1996.

NTO Orlando Partners/Orlando Naval Training Center. Regulatory Plan. Orlando, FL. Undated.

Orange County, Florida/Planning Division, Urban Design Section. Commercial Design Standards Guidebook.

Oregon Department of Transportation, Transportation Development Branch. Best Management Practices for Transportation/Land Use Planning. 1992.

Oregon Department of Transportation. Section 660-012-0045 (5)(e).)

Oregon Department of Transportation/Oregon Department of Land Conservation and Development. Main Street... When a Highway Runs Through It: A Handbook for Oregon Communities. 1999.

Pratt, Richard H. and Timothy J. Lomax. Performance Measures for Multimodal Transportation Systems. Transportation Research Record, No. 1518, Washington, DC: National Academy Press. 1996

Santa Clara Valley Transportation Authority. VTA Bicycle Technical Guidelines, September 2, 1999.

Schwartz, Marcy, Miley Lee Merkhofer, and Richard Upton. Innovative Approach to MultipleCriteria Evaluation of Multimodal Alternatives: Newberg-Dundee Transportation Improvement Project Case Study, Transportation Research Record. No. 1617. Washington, DC: National Academy Press, pp. 139-149. 1998

Stevens/Garland Associates and SR Associates/County of San Diego Department of Planning and Land Use. Mode Enhancements through Land Use Design: Development Design Strategies to Encourage the Use of Alternative Transportation Modes. 1991.

Strate, Harry E, Elizabeth Humstone, Susan McMahon, Lucy Gibson, and Bruce D Bender. Functional Classification for Multimodal Planning. Transportation Research Record, No. 1606. Washington, DC: National Academy Press, pp. Washington, DC: National Academy Press, pp. 5163. 1997

The Corporation of the Town of Markham, Development Services Commission. Design Implementation Guidelines, June 1996.

The Town of Davidson, North Carolina. Planning Ordinance. June 11, 2001.

Transportation Rule Working Group/Oregon Chapter of American Planning Association/Oregon Department of Land Conservation and Development/Oregon Department of Transportation. Recommendations for Pedestrian, Bicycle and Transit-Friendly Development Ordinances. Working Draft. 1993. 
University of North Carolina/Highway Safety Research Center/Florida Department of Transportation. Florida Pedestrian Planning and Design Handbook. 1999.

U.S. Department of Transportation. Federal Highway Administration. Pedestrian Facilities Users Guide: Providing Safety and Mobility. No. FHWA-RD-01-102. March, 2002.

Victoria Department of Planning and Housing. Victorian Code for Residential Development: MultiDwellings. Victoria, Australia: Department of Planning and Housing. 1992.

Victoria Department of Planning and Housing. Victorian Code for Residential Development: Subdivision and Single Dwellings. Victoria, Australia: Department of Planning and Housing. 1992.

West, Jim and Allen Lowe. Integration of Transportation and Land Use Planning through Residential Street Design. ITE Journal. 1997.

Wheeler, Porter K. Transportation Cost Allocation: Applying Cost Allocation in a Multimodal Environment Source. Transportation Research Record. No. 1558. National Academy Press, pp.8-16. 1996

Wilmington Area Planning Council. Wilmapco Mobility Friendly Design Standards. November 1997. Appendix E: Middletown Zoning Recommendations.

Wilmington Area Planning Council. Old Newark Traffic Calming Plan. March 2002.

Ziegler, Edward and Greg Byrne. Zoning, New Urbanist Development, and the Fort Collins Plan. Zoning News. Chicago: American Planning Association. 1998. 
